Rapp. Grønlands geol. Unders. 88, 41-49 (1979)

\title{
UPPERMOST ORDOVICIAN AND SILURIAN GEOLOGY OF NORTH-WEST PEARY LAND, NORTH GREENLAND
}

\author{
J. M. Hurst
}

\section{Introduction}

In 1978 mapping was concentrated in the area of Peary Land, between J. P. Koch Fjord and Odins Fjord, south of a line connecting Nordpasset with Harebugt and the western end of Frederick E. Hyde Fjord (fig. 11 and map 1). Prior to this season the Silurian geology of the area was largely unknown. Previous investigations of the platform sediments of Peary Land (Koch, 1923; Troelsen, 1949, 1956; Jepsen, 1971) had mainly concentrated on the older Lower Palaeozoic and Precambrian rocks of southern Peary Land. The only comprehensive account of the Lower Palaeozoic rocks of the platform (including Silurian) of Peary Land, by Peel \& Christie (1975) and Christie \& Peel (1977) was based on a single composite section in the Børglum Elv district, north of Jørgen Brønlund Fjord (fig. 11). A localised detailed study of a Silurian carbonate buildup in the Børglum Elv region (Mayr, 1976 ) is the only other aspect of Silurian geology studied in the whole area.

The mapping area revealed a complete and complex Lower Silurian carbonate sequence ranging in age from lowest Llandovery to at least Wenlock. Younger beds ranging into the Ludlow are probably present, but verification of their presence must await identification of graptolite faunas. Basically the sequence breaks into two distinct divisions, corresponding to the shelf carbonates in the southern area and the basin shales, conglomerates and finally turbidites of the north. The initially distal turbites with shale interbeds overlap from the northern basin onto the southern shelf carbonates which are then abruptly terminated.

Besides the north-south facies change there is also an east-west change along strike. The Silurian sequence seen in Odins Fjord is almost identical in facies and thickness to that described by Christie \& Peel (1977) in Børglum Elv. The same sequence also occurs to the west in the southern extension of Adolf Jensen Fjord although the area in between is unexposed due to Hans Tavsens Iskappe (fig. 11). Between Adolf Jensen Fjord and J. P. Koch Fjord, under Hans Tavsens Iskappe the Silurian sequence of Odins Fjord changes. In J. P. Koch Fjord a totally different succession of shelly limestones follows conformably from the Ordovician.

On the basis of present knowledge, the sequences can be divided into several formations and members, but these are not yet formalised. In the environs of J. P. Koch Fjord there are three formations and seven members in the shelf carbonate sequence, all of which are new. Two new formations divisible into eight members have been established in the Odins Fjord carbonate sequence. The basin sequence including all the clastic deposits which lap onto the shelf in the eastern part of the area will eventually have to be accorded group status, divisible into several formations. 


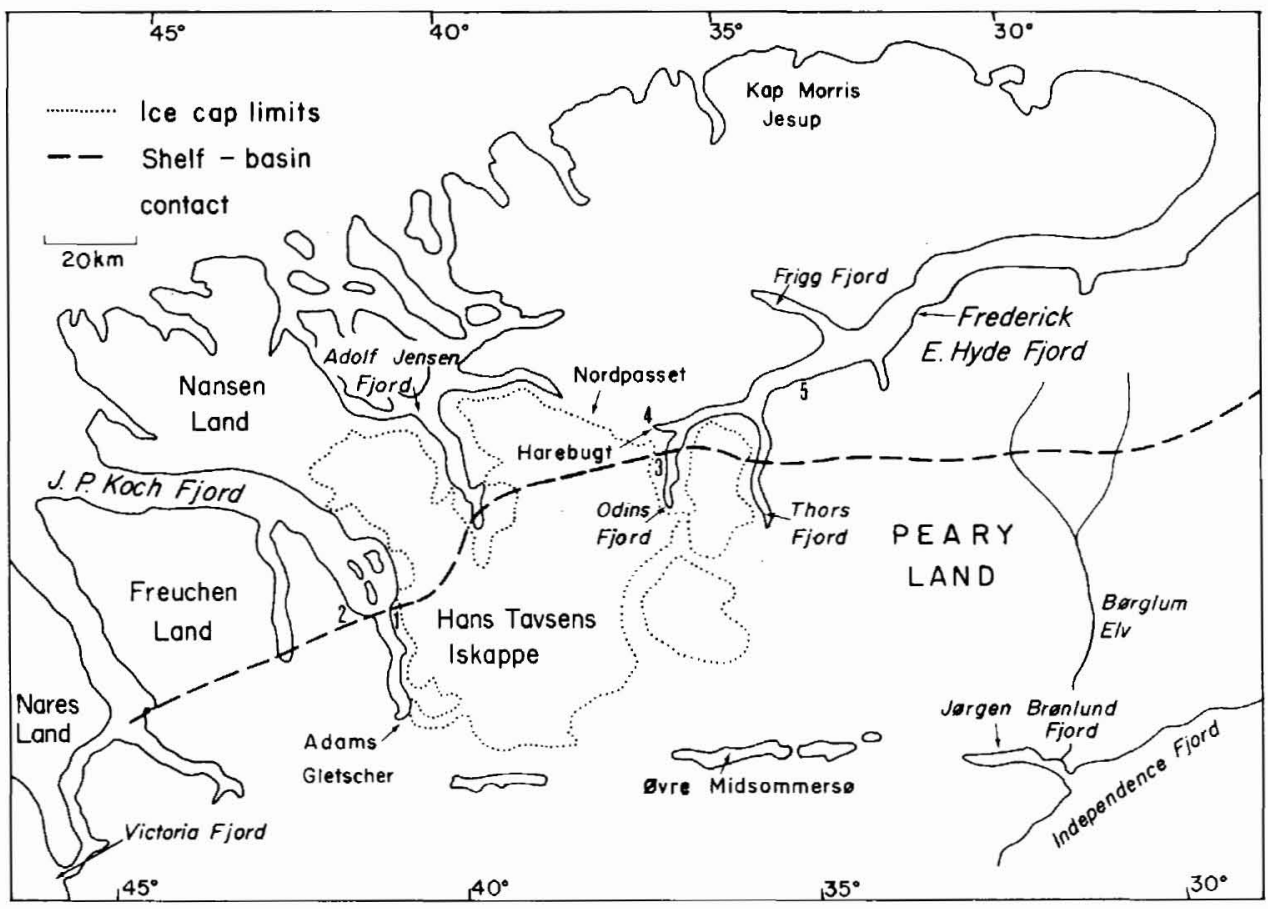

Fig. 11. Locality map of central and north-west Peary Land, also showing shelf basin contact during Ordovician-Silurian. Numbers refer to the following: 1 , is the platform carbonate section locality in $\mathrm{J}$. P. Koch Fjord (fig. 12); 2, is the section locality through the clastics in J. P. Koch Fjord (fig. 13); 3, locality for the section through the clastics which onlap the platform (fig. 13); 4 \& 5, are the localities after which the basinal clastic sequence is based.

In the following, the formations and members of the carbonates are briefly described in ascending order starting with J. P. Koch Fjord. The basinal clastic sequence is treated separately.

\section{Carbonate sequence in J. P. Koch Fjord area}

\section{Dolomite formation}

Some $70 \mathrm{~m}$ of thin to medium bedded and more massive, generally dark grey, limy dolomites conformably overlie the Ordovician Børglum River Formation (fig. 12). The formation is well exposed in the cliffs on the eastern side of J. P. Koch Fjord area and is divisible into two members.

\section{Member $A(40 \mathrm{~m})$}

This lower unit is very recessive and consists of mottled sugary white to grey, very thin bedded, limy dolomites which are occasionally faintly laminated and with intraformational 


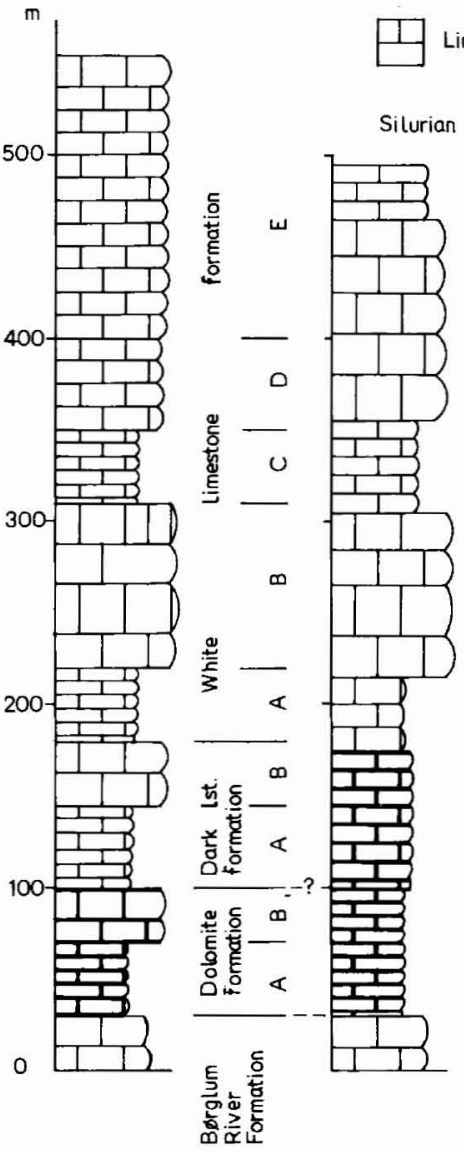

3

Limestone Dolomite
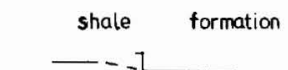

Fig. 12. Generalised platform carbonate sections in $J$. P. Koch Fjord (1), Odins Fjord (2) and Børglum Elv (3) after Christie \& Peel (1977). For localities see fig. 11 .

conglomerates. Fossils are extremely rare and of low diversity; the main forms being recrystallised tabulate corals and actinoceratid cephalopods.

\section{Member B (30 m)}

The upper unit is a massive cliff forming (fig. 12) dark grey to black limy dolomite. No bedding was observed and the whole unit is heavily recrystallised with many calcite vugs. Again the fauna is sparse and of low diversity, generally consisting of recrystallised tabulate corals, both Favosites and Halysites, stromatoporoid fragments and orthocone cephalopods.

\section{Age}

The formation rests conformably on the Børglum River Formation which possibly reaches into early Richmond (Ashgill) age in the Børglum Elv region (Christie \& Peel, 1977). The 
dolomites do not contain any fossils diagnostic of age. However, in the base of the overlying dark limestone formation Maclurites sp. occurs, indicating the dolomites to be of Ordovician age, presumably late Ordovician on account of their stratigraphic position.

\section{Dark limestone formation}

The dolomite formation is conformably followed by a variable sequence of limestones with subordinate limy dolomites in the basal part. The whole unit is $80 \mathrm{~m}$ thick and locally maybe richly fossiliferous. Two members are recognisable (fig. 12).

\section{Member $A$ (44 m)}

This recessive unit consists of an alternation of black, hard, nodular, splintery limestones (up to $12 \mathrm{~m}$ thick) which are occasionally mottled, with thin (2-3 m) units of creamy white laminated, recrystallised dolomite. The top of the member is a massive creamy white, laminated and mottled dolomite with numerous small calcite filled vugs.

In the basal beds coquinas of thick shelled virgianid (pentameroid) brachiopods occur. These, along with scattered tabulate corals, cephalopods and stromatoporoids are the main faunal constituents. All members of the fauna are far more abundant in the darker limestones.

\section{Member B (36 m)}

This massive, cliff forming unit consists of medium bedded, dark grey, vuggy and mottled limestone, with a high dolomite content in the basal beds. The limestone is characterised by massive domed and lamellar stromatoporoids and horizons rich in large ostracods are common.

Age

The formation probably spans the Ordovician-Silurian boundary. The lowest horizons of Member A contain Maclurites and are possibly of uppermost Ordovician (latest Richmond) age. No other diagnostic faunas have yet been located but the majority of the formation probably belongs to the Lower Llandovery (Ruddanian).

\section{White limestone formation}

A homogeneous sequence of generally light grey limestone conformably overlies the previous formation and is divisible into 5 members (fig. 12). The whole unit is $380 \mathrm{~m}$ thick.

\section{Member $A(40 \mathrm{~m})$}

The basal unit is a recessive light grey to white, lime mudstone which is faintly laminated and with very small calcite filled vugs. Styolites are characteristic but there is no macrofauna. 
Member $B(90 \mathrm{~m})$

A thick bedded, massive, cliff forming, light to medium grey, lime mudstone with pods of radiating calcite, up to $10 \mathrm{~cm}$ across. In the upper $20 \mathrm{~m}$ there are thinly bedded $(c .2-10 \mathrm{~cm})$ black limestones up to $50 \mathrm{~cm}$ thick. Fossils are rare and consist mainly of stromatoporoids and Favosites.

Member $C(40 \mathrm{~cm})$

This recessive unit consists of $40 \mathrm{~m}$ of very thin bedded or nodular, black and mottled lime mudstone. Fossils are very common, including brachiopods, trilobites, ostracods and corals. There is a prominent $5 \mathrm{~m}$ thick band of Harpidium? just below the top of the unit.

Member D (50m)

These light to medium grey, lime mudstones are thin to medium bedded. Pockets of scutelluid trilobites and atrypoid brachiopods are common in the lower part. In general the whole member is very fossiliferous with trilobites, brachiopods, gastropods, ostracods and bivalves.

\section{Member $E(160 \mathrm{~m})$}

The member begins with $10 \mathrm{~m}$ of recessive black platy lime mudstones which form a distinctive lower boundary to the unit. Above comes a thin to medium bedded unit of light to medium grey, lime mudstone which in places is nodular. Interbedded in the top $30 \mathrm{~m}$ are thin horizons of black nodular or platy, lime mudstones. The fauna is dominated by large bulbous and lamellar stromatoporoids and tabulate corals. Harpidium sp. occurs in the upper $20 \mathrm{~m}$.

Age

At present the age of the base of the formation is unknown. The presence of Harpidium sp. suggests a C3 Late Llandovery (Fronian) to Ludlow age. The faunal assemblage in member $D$ is very reminiscent of other late Llandovery assemblages from central Peary Land. The greater part of the formation is probably Llandovery and it may extend into the Wenlock or even Ludlow.

\section{Carbonate sequence in Odins Fjord area}

The sequence here is very similar to Børglum Elv (Christie \& Peel, 1977) and thus is not described in great detail (fig. 12). Reference is particularly made to the differences. The informal lithostratigraphic terms of Christie \& Peel are used throughout. 


\section{Un-named Silurian(?) dolomite formation}

This unit is some $5 \mathrm{~m}$ thinner than in the Børglum Elv area, but the two members are still present, the upper one accounting for the $5 \mathrm{~m}$ loss in thickness (fig. 12). The lower part of the lower member is heavily mottled as in the upper Børglum River Formation and there is a complete gradation from the limestones of the Børglum River Formation into the dolomite formation. The poor fauna of the lower dolomite member precludes age assignment but it is probably Late Ordovician (Richmond) as it rests conformably on the Børglum River Formation of this age. Smooth virgianid brachiopods low in the upper member probably indicate a Lower or Middle Llandovery age.

\section{Un-named Silurian limestone formation}

Member $\mathbf{A}$ is $5 \mathrm{~m}$ thicker in Odins Fjord than in the Børglum Elv area. Member $\mathrm{B}$ maintains a constant thickness throughout the whole region, whereas member $\mathrm{C}$ thins from $60 \mathrm{~m}$ at Børglum Elv to $40 \mathrm{~m}$ in Odins Fjord. Member D thickens from $30 \mathrm{~m}$ to $50 \mathrm{~m}$ at Odins Fjord, but the unit thins to $40 \mathrm{~m}$ down dip towards the basin (fig. 12).

Members $E$ and $F$ are those showing most variation. Member $E$ thickens to $110 \mathrm{~m}$ in the southern part of Odins Fjord, whilst member F maintains a constant $35 \mathrm{~m}$ thickness. Across strike into the basin member $E$ thickens to $145 \mathrm{~m}$ and concomitantly member $F$ is reduced to $5 \mathrm{~m}$ of creamy white grey nodular lime mudstone.

\section{Basinal clastic sequences in the Nordpasset area}

Preliminary examination of sections immediately north and south of the western end of Frederick E. Hyde Fjord revealed a basic bipartite basinal clastic sequence (fig. 11). This area is in the southernmost part of the fold belt. From below:

\section{Shale - conglomerate formation}

This unit consists of dark grey to black, fissile, graptolitic shales and pencil slates interbedded with thick (c. 1 to $40 \mathrm{~m}$ ) limestone conglomerates. Chert bands and laminated, quartz turbidites occur in the shales. The conglomerates are generally clast supported with the largest clasts reaching up to $1 \mathrm{~m}$ in diameter. Some clasts can be matched to the Lower Palaeozoic shelf limestone sequences.

Dawes \& Soper (1970) first reported the presence of this unit which is known to be of Lower Ordovician and younger age. The total thickness is unknown but must exceed $500 \mathrm{~m}$.

\section{Un-named Silurian flysch formation}

In the basinal areas this follows conformably from the unit described above, and is the earliest expression of the turbiditic sequence which occurs throughout North Greenland (Dawes 1971, 1976). The unit consists of well bedded fine to medium grained, quartzitic 
sandstones which weather grey brown, interbedded with thinner shale and siltstone units. Some fine grained matrix supported conglomerates also occur. There is a great deal of internal variation in the unit both laterally and vertically.

\section{Odins Fjord clastic sequences}

\section{Un-named Silurian shale formation}

As in the Børglum Elv region the Silurian limestones of Odins Fjord are succeeded by the un-named Silurian shale formation. This unit, which is about $100 \mathrm{~m}$ thick, is a distal turbidite sequence apparently only known in the shelf areas. Typically it consists of soft, black shales with silty shale and fine sand interbeds and a few thin black, fine grained silty limestones. Graptolites are common but the precise age of the unit is not known yet, although it is probably of Upper Llandovery and younger age.

Traced northwards the unit thins to approximately $60 \mathrm{~m}$ of coarse, micaceous siltstone interbedded with mud supported, fine grained polymict conglomerates (fig. 13).

\section{Un-named Silurian flysch formation}

An undisturbed $400 \mathrm{~m}$ section of turbidites overlies the previous formation and is the southerly extension of the same formation in the basinal areas. As a broad lithological and stratigraphical unit, it is essentially the same as described by Christie \& Peel (1977) in the northern Børglum Elv area. Total thickness of the unit probably exceeds $1000 \mathrm{~m}$.

J. P. Koch Fjord

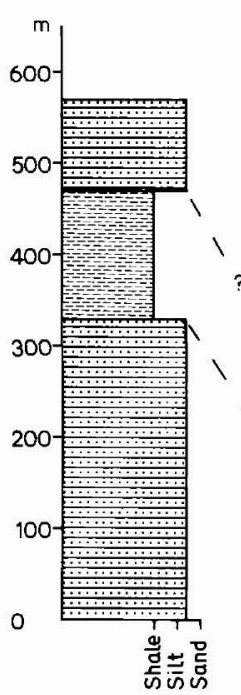

Odins Fjord

South North

Turbidites (in part Flysch)

Shales

Siltstone

Siltstone and

conglomerate

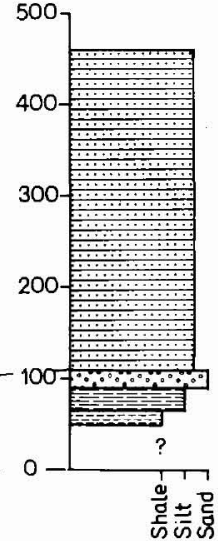

Fig. 13. Generalised clastic sections in north-west Peary Land. 


\section{J. P. Koch Fjord clastic sequences}

A $600 \mathrm{~m}$ clastic succession in juxtaposition with the shelf carbonates is best exposed in the west side of J. P. Koch Fjord, in Freuchen Land (fig. 13). A basic tripartite lithological subdivision is recognisable:-

(a) A lower turbiditic unit, at least $450 \mathrm{~m}$ thick, of which the lower $100 \mathrm{~m}$ is poorly exposed. Although the age of this part of the flysch formation is not known, it may represent the oldest part of this facies and stratigraphically equate with the lowest part of the same unit seen in Frederick E. Hyde Fjord.

(b) This is succeeded by $140 \mathrm{~m}$ of silty, black shale, which weathers into black soot with sulphurous stains. Harder, fine sand turbidites up to $10 \mathrm{~cm}$ and minor bioclastic debris beds are present. The age of the unit is not known but it may correlate with the un-named Silurian shale formation further eastwards (fig. 12).

(c) Above is $100 \mathrm{~m}$ of sandstone and siltstone turbidites.

\section{Basin shelf contact and carbonate mounds}

Christie \& Peel (1977) noted the presence of carbonate buildup structures at the summit of the Silurian carbonate sequence. The mounds are composed essentially of stromatoporoid and algal boundstone with concomitant breccia beds (Mayr, 1976). They appear to root themselves in the top of member $\mathrm{E}$ of the un-named Silurian limestone formation and grow simultaneously with the deposition of member $F$ and at least part of the overlying un-named Silurian shale formation. An analogous environmental situation is present in Odins Fjord but no carbonate buildups occur. Here the shales and turbidites simply lap onto the shelf carbonates, in layer-cake fashion.

The situation in J. P. Koch Fjord is apparently different. The Silurian (plus Upper Ordovician?) limestones dip gently towards the north but abruptly stop. From a distance the limestones appear to plunge steeply under the turbidites, but closer examination reveals many of the beds are slumped and brecciated and give a false impression of bedding. Some small, isolated knolls resembling foreslope mud mounds (cf. Wilson, 1974). The abrupt contact between shelf and basinal turbidites is angled at about $60^{\circ}$ to the north and is probably a fault controlled feature.

Thus, the contact between shelf and basin facies is varied. A simple onlap situation occurs in the east whereas an abrupt scarp contact (fault controlled?) is present in the west. In J. P. Koch Fjord adjacent beds of turbidites and limestones may have totally different ages.

\section{Structure}

The carbonate sediments of the Silurian follow conformably on from the Ordovician, in typical layer cake fashion. They dip gently towards the north where they are abruptly replaced by basin clastics. Towards the east the upper carbonate sequences dip steeply (up to $20^{\circ}$ ) below the onlapping clastics. The un-named Silurian shale formation and approximately the lowest $600 \mathrm{~m}$ of the flysch formation also dip gently towards the north. However, 
above this horizon, throughout the whole area, there is an abrupt change from flat lying or gently dipping turbidites to steeply dipping and overturned units. Spatially this transition is abrupt (over less than $2 \mathrm{~km}$ ) and geographically it occurs some $5 \mathrm{~km}$ south of an east-west line parallel with the inner part of Frederick E. Hyde Fjord. A few normal faults aligned north-west-south-east are the only important structural elements south of this line.

\section{Basic dykes}

In the central and northern parts of the area a swarm of vertical basic dykes is aligned north-west-south-east. The dykes are vertical features and are less common further south in the carbonates, where they weather to a distinctive brownish red colour. They are softer than the surrounding carbonates, thus forming prominent gullies. Tilting and slight rotation of carbonate blocks occurs, centered around some dykes, but very little, if any, displacement is involved.

The colour of the dykes is difficult to distinguish from the colour of the turbiditic sandstones, but as the basaltic material is more resistant it stands out as prominent walls. Over in the central part of the region immediately south of Adolf Jensen Fjord there are impressive dyke swarms perhaps accounting for 5 per cent of exposure.

\section{References}

Christie, R. L. \& Peel, J. S. 1977: Cambrian-Silurian stratigraphy of Børglum Elv, Peary Land, eastern North Greenland. Rapp. Grønlands geol. Unders. 82, 48 pp.

Dawes, P. R. 1971: The North Greenland fold belt and environs. Bull. geol. Soc. Denmark 20, 197-239.

Dawes, P. R. 1976: Precambrian to Tertiary of northern Greenland. In Escher, A. \& Watt, W. S. (edit.) Geology of Greenland, 248-303. Copenhagen: Geol. Surv. Greenland.

Dawes, P. R. \& Soper, N. J. 1970: Geological investigations in northern Peary Land. Rapp. Grønlands geol. Unders. 28, 9-15.

Jepsen, H. F. 1971: The Precambrian, Eocambrian and early Palaeozoic stratigraphy of the Jørgen Brønlund Fjord area, Peary Land, North Greenland. Bull. Grønlands geol. Unders. 96 (also Meddr Grønland 192, 2) $42 \mathrm{pp}$.

Koch, L. 1923: Preliminary report upon the geology of Peary Land, Arctic Greenland. Amer. J. Sci. (5), 5, 189-199.

Mayr, U. 1976: Middle Silurian reefs in southern Peary Land, North Greenland. Bull. Can. Petrol. Geol. 24, 440-449.

Peel, J. S. \& Christie, R. L. 1975: Lower Palaeozoic stratigraphy of southern Peary Land, eastern North Greenland. Rapp. Grønlands Geol. Unders. 75, 21-25.

Troelsen, J. C. 1949: Contributions to the geology of the area round Jørgen Brønlunds Fjord, Peary Land, North Greenland. Meddr Grønland 149, 2, 29 pp.

Troelsen, J. C. 1956: The Cambrian of North Greenland and Ellesmere Island. In El sistema Càmbrico, su paleogeografía y el problema de su base. 20 Congr. geol. int. Mêxico. Symp. 3(1), 71-90.

Wilson, J. L. 1974: Characteristics of carbonate-platform margins. Bull. Amer. Ass. Petrol. Geol. 58, 810-824. 